\title{
FAeCAL EGg COUNTS ARE REPRESENTATIVE OF DIGESTIVE-TRACT STRONGYLE WORM BURDENS IN SHEEP AND GOATS
}

\author{
CABARET J.*, GASNIER N.* \& JACQUIET P.*
}

\section{Summary :}

The relationship between faecal egg counts and worm burdens in sheep and goats was studied in a large array of environments, from temperate (ewes, lambs or dairy-goats in France) or steppic (ewes in Middle-Atlas of Morocco) to Sahelian (young sheep and goats of Mauritania in West Africa) climates. The studied temperate worm communities were dominated by Teladorsagia and Trichostrongylus sp., and those from steppic areas by Teladorsagia, Marshallagia and Trichostrongylus sp.;

Haemonchus contortus was highly predominant in the Sahelian regions. The fertility of worms depended on density 110 to $50 \%$ of variancel and presence of $H$. contortus to a lesser extent. For sheep and goats from several temperate and steppic areas, a good relationship between egg counts and worm burdens was established $(r=0.62)$. It was ameliorated when the percentage of $H$. contortus, the most prolific species was incorporated in the model. The predictive value of faecal egg count for assessing worm burden was only of interest for groups of hosts.

KEY WORDS : sheep, goasts, egg count, worm burden, nematode, densitydependent fertility.

\section{INTRODUCTION}

T he use of digestive-tract strongyle faecal egg counts for observational or experimental studies in naturally infected sheep and goats have been used extensively for decades. The rationale behind the use of this technique is based on the assumption that there is a defineable relationship between faecal egg count and nematode worm burdens. This could provide meaningful information on the strongyle status of a flock or herd. It has been used more recently as a selection criterion in all breeding programs for resistance of ruminants to strongyle infection (Gruner, 1991 among others) but there is a considerable scepticism over the value of the faecal egg counts as an individual indicator of the intensity of

\footnotetext{
* INRA, Station de Pathologie aviaire et de Parasitologie, Unité d'Écologie des parasites, 37380 Nouzilly, France.

Correspondence: Jacques Cabaret. Tel: 3347427768.

Fax: 3347427774 - e-mail: cabaret@tours.inra.fr.
}

Résumé : L'EXCRÉTION DES CEUfS REPRÉSENTE BIEN LA CHARGE PARASITAIRE CHEZ LES STRONGLES DIGESTIFS DES OVINS ET DES CAPRINS

La relation entre l'excrétion des œufs et le nombre de parasites hébergés par les ovins et les caprins a été étudiée dans une gamme étendue d'environnement, tempéré /brebis, agneaux ou chèvres laitières en France), steppique (brebis du Moyen Atlas au Maroc) ou sahélien (jeunes ovins et caprins de Mauritanie). Les communautés de vers des zones tempérées étudiées sont dominées par Teladorsagia et Trichostrongylus sp. et ceux des zones steppiques par Teladorsagia, Marshallagia et

Trichostrongylus sp.; Haemonchus contortus était l'espèce largement prédominante en zone sahélienne. La fertilité des vers dépend de leur densité (10 à $50 \%$ de la variance) et partiellement de la présence d'Haemonchus. Malgré ces facteurs de variation, une bonne relation entre l'excrétion d'oeufs et la charge parasitaire a pu être établie $(r=0,62)$. Cette relation peut encore être améliorée si le pourcentage $d^{\prime} \mathrm{H}$. contortus, espèce la plus prolifique, est incorporé dans le modèle. La valeur prédictive du dénombrement d'œufs pour apprécier le nombre de vers n'a d'intérêt réel que pour des groupes d'hôtes.

MOTS CLÉS : ovin, caprin, excrétion d'œufs, charge parasitaire, nématode, fertilité densité-dépendante

infection. The digestive-tract strongyles are not randomly distributed in their hosts (Anderson \& Gordon, 1982; Boag, Hackett \& Topham, 1992) but tend to be aggregated, with a variance greater than the mean. Distribution of faecal egg counts between hosts is also aggregated (Hunter \& Quenouille, 1952). It is then no surprise that relationship between faecal egg counts and worm burden may be difficult to establish due to sampling difficulties. This was evidenced on a large sampling in lambs and ewes: individual faecal egg counts and worm counts were not always related, depending on the origin of data set (Cabaret \& Ouhelli, 1984). This might be due in part to the fact that per capita parasite egg production is dependent on worm density (see Fleming, 1988, for Haemonchus contortus experimental infections) and species (see Cabaret \& Ouhelli, 1984 for natural infections). Nevertheless, positive relationship between egg and worm counts in lambs (McKenna, 1987) or dairy-goats (Cabaret \& Gasnier, 1994) were evidenced, and gives support to the aim of the present work: to provide a simple relationship between faecal egg counts and worm burdens 
in sheep and goats under various environments and to assess the influence of density-dependence on this relationship. As individual relationship between egg output and worm burden is not fully reliable, we will investigate pooled data of hosts with similar level of infection as assessed from egg counts or similar exposure to infection as they belong to the same farm. The influence of a well prevalent species, Haemonchus contortus, with high fecundity, will be also evaluated.

\section{MATERIALS AND METHODS}

\section{THE SAMPLED HOSTS}

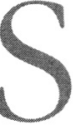
everal data sets were used and their characteristics are shown in table I. They were different in geographical origins (from temperate to Sahelian), in species (sheep and goats) or age (lambs and ewes) of hosts, and in strongyle species (very low versus very high percentage of Haemonchus contortus). Several data sets have been partly published (lambs in three regions of France or ewes from Morocco:
Cabaret \& Ouhelli, 1984) but were reanalysed, and the others were new (data from dairy-goats in French Touraine or sheep and goats from Mauritania). Small ruminants originated either from identified farms (French sheep and goat data; Mauritania) or were collected from slaughter-house (Morocco data). They were bred under a large range of climatic conditions: sahelian (annual rainfall $150 \mathrm{~mm}$, average temperature $26^{\circ} \mathrm{C}$-Mauritania data), steppic (annual rainfall $600 \mathrm{~mm}$, average temperature $21^{\circ} \mathrm{C}$-Moroccan data) or temperate (annual rainfall $600 \mathrm{~mm}$, average temperature $11^{\circ} \mathrm{C}$-French sheep and goat data) climates.

\section{PARASITOLOGICAL TECHNIQUES}

For all studies each host was sampled once for faeces and necropsied with the exception of the dairy-goats of Touraine in France for which five faecal egg counts were performed in order to assess more accurately the number of excreted eggs per gram (EPG). Only the hosts with positive EPG were included in the studies, as nil EPG values may correspond to very low infection (technical artefact) or absence of infection. Modi-

\begin{tabular}{|c|c|c|c|c|c|c|c|}
\hline \multirow[b]{2}{*}{ Host (no of pool) } & \multirow[b]{2}{*}{ Region } & \multirow[b]{2}{*}{ Period of study } & \multicolumn{4}{|c|}{ Percentage of dominant species } & \multirow[t]{2}{*}{ Accessory species } \\
\hline & & & H. con & T. cir & T. Axei & T. col & \\
\hline $\begin{array}{l}18 \text { lambs from } 3 \text { farms } \\
5 \text { months old (6) }\end{array}$ & Allier, France & July & 8 & 74 & 1 & 14 & $\begin{array}{l}\text { Chabertia ovina and } \\
\text { Oesophagostomum } \\
\text { venulosum }\end{array}$ \\
\hline $\begin{array}{l}28 \text { lambs, from } 2 \text { farms, } \\
\text { approximately } 1 \text { year } \\
\text { old ( } 4 \text { ) }\end{array}$ & Aveyron, France & April to January & 12 & 72 & 4 & 7 & $\begin{array}{l}\text { C. ovina, Cooperia sp. } \\
\text { and O. venulosum }\end{array}$ \\
\hline $\begin{array}{l}24 \text { lambs, from } 2 \text { farms, } \\
5 \text { months old ( } 4 \text { ) }\end{array}$ & Touraine, France & June to August & 9 & 45 & 9 & 18 & $\begin{array}{l}\text { C. ovina, Cooperia sp. } \\
\text { and O. venulosum }\end{array}$ \\
\hline 12 lambs, 1 year old (3) & $\begin{array}{l}\text { Gorgol, } \\
\text { Mauritania }\end{array}$ & All year & 98 & 0 & 0 & 1 & $\begin{array}{l}\text { C. ovina and Oesopha- } \\
\text { gostomum columbia- } \\
\text { num }\end{array}$ \\
\hline 6 ewes, from 3 farms (3) & Allier, France & May & 4 & 66 & 8 & 8 & $\begin{array}{l}\text { C. ovina, and O. venu- } \\
\text { losum }\end{array}$ \\
\hline 15 ewes, from 3 farms (5) & Aveyron, France & April to January & 1 & 70 & 3 & 14 & $\begin{array}{l}\text { C. ovina, Cooperia sp. } \\
\text { and O. venulosum }\end{array}$ \\
\hline 99 ewes (14) & $\begin{array}{l}\text { Middle-Atlas } \\
\text { Morocco }\end{array}$ & 3 years monthly & 0 & 43 & 15 & 30 & $\begin{array}{l}\text { Marshallagia marshalli, } \\
\text { C. ovina and } \\
\text { O. venulosum }\end{array}$ \\
\hline $\begin{array}{l}24 \text { goats over } 3 \text { years old, } \\
\text { from } 12 \text { farms (12) }\end{array}$ & Touraine, France & Autumn & 2 & 54 & 1 & 40 & $\begin{array}{l}\text { C. ovina and O. venu- } \\
\text { losum }\end{array}$ \\
\hline $\begin{array}{l}20 \text { goats, over } 1 \text { year } \\
\text { old ( } 3 \text { ) }\end{array}$ & $\begin{array}{l}\text { Gorgol, } \\
\text { Mauritania }\end{array}$ & All year & 98 & 0 & 0 & 1 & O. columbianum \\
\hline
\end{tabular}

Table 1.- Description of the hosts, regions and species of digestive-tract strongyles (H. con, Haemonchus contortus; T. cir, Teladorsagia circumcincta; T. axei, Trichostrongylus axei; T. col, Trichostrongylus colubriformis and T. vitrinus) (data pooled on several hosts into 54 pools). 
fied McMaster technique was employed using either magnesium sulphate (ewes from Morocco, goats from Touraine), potassium iodomercurate (lambs and ewes in France) or a mixed solution of sodium chloride and zinc chloride as flotation liquids (sheep and goats from Mauritania), 15 eggs per gram corresponding to one egg seen in the whole McMaster slide. The worms were counted on total washings of mucosae and 1:10 aliquot of contents for abomasum and small intestine or totality for large intestine. Identification of worms to species was based on Skrjabin, Shikobalova \& Schultz, 1954.

\section{ANALYSIS OF DATA}

The worm burdens established on 242 individual necropsy data were arranged into 54 pooled data before analysis. The pooling procedure was the following: two goats per farm studied (Touraine), two (Allier) to five (Aveyron) ewes per farm, three to seven lambs per necropsy period (Allier, Aveyron and Touraine), seven to eight ewes (Morocco) based on intensity of infection for each of the three years of study, six to seven young sheep or goat (Mauritania) based on intensity of infection. Least-square regressions between faecal egg and worm counts were performed using the Simstat software (Péladeau \& Lacouture, 1993) after natural logarithm transformation to stabilize the variance when needed; the bootstrap resampling procedure was used to assess the stability of the established regressions.

\section{RESULTS}

\section{RELATIONSHIP BETWEEN EPG AND THE NUMBER} OF WORMS

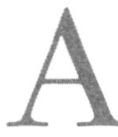

unique relationship (Fig. 1, 54 pairs) between worm burden and EPG in the different sets of data is shown in the following regression (that remains significant at $\mathrm{P}<0.02$ in all the 50 resamplings): Log Worms $=3.08+0.72$ Log EPG $(r=0.62 ; P<0.001)$. It could grossly predict the worm burden in a large array of conditions as standard error on intercept (0.71) and slope coefficient (0.12) were relatively small. Nevertheless, the data from Mauritania were all located below the regression line; it indicated that egg counts corresponded to a lower worm burden than should be expected. The predictions of worm burdens at $\mathrm{P}=0.05$ were (data not shown): 67-493 for 20 EPG, 898-2440 for $400 \mathrm{EPG}, 1808-4910$ for $1000 \mathrm{EPG}$ which appears as reasonably accurate.

LOCAL REGRESSIONS BETWEEN FAECAL EGG COUNTS AND WORM BURDENS

Better predictions might be attained when local regressions were established. The best fit for the relationship

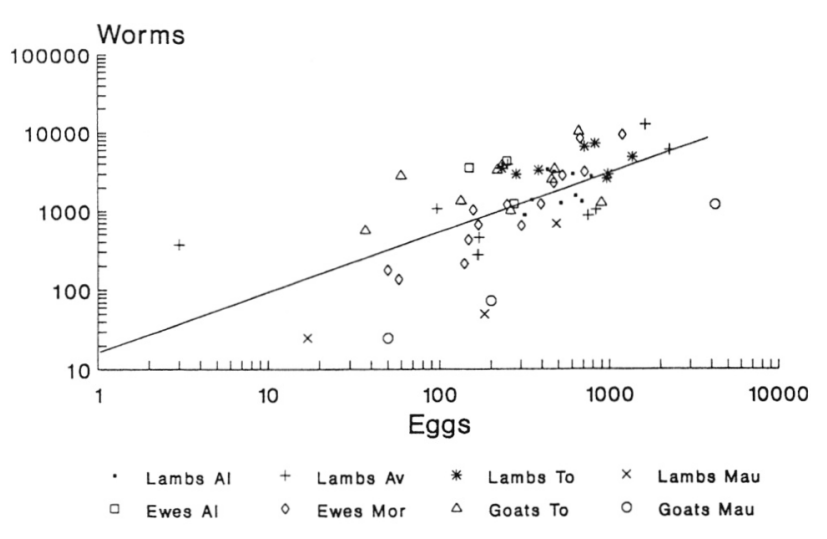

Fig. 1. - Relationship between worm burdens (Worms) and faecal egg counts (Eggs: egg per gram of faeces) in pooled data from France (Al: Allier, Av: Aveyron, To: Touraine), Morocco (Mor) and Mauritania (Mau).

between the number of worms and EPG (natural logarithms) were for dairy-goat results:

Log Worms $=0.11+1.20 \log$ EPG $(r=0.80 ; \mathrm{P}<0.001)$. The obtained regressions on goat data were significant at $\mathrm{P}<0.05$ when data were bootstraped in 150 out of 170 cases; the non significant cases presented a probability $\mathrm{P}$ ranging from 0.06 to 0.15 .

The corresponding regression for data from lambs and ewes (Morocco and France) was very similar to the goat one:

Log Worms $=-0.22+1.24 \log$ EPG $(r=0.84 ; \mathrm{P}<0.001)$. The Mauritania data were regressed as follows:

Log Worms $=1.125+0.651 \log$ EPG $(r=0.73 ; \mathrm{P}<0.002)$.

\section{INFLUENCE OF HOST}

The age of host did not modify significantly the relationship between worm burdens and eggs. Conversely, the species of host modified the relationship:

Goats: Log Worms $=4.72+0.46 \log$ EPG $(r=0.34$; $\mathrm{P}=0.21$ ).

Sheep: Log Worms $=2.42+0.81$ Log EPG $(r=0.74$; $\mathrm{P}<0.001)$.

PERCENTAGE OF $H$. CONTORTUS SPECIES MODIFIES THE RELATIONSHIP BETWEEN WORM BURDENS AND FAECAL EGG COUNTS

The relationship worm-egg was improved when the percentage of $H$. contortus $(\mathrm{Hae}=$ percentage of $H$. contortus +0.1$)$ in the community was taken into account:

Log Worms $=2.89+0.75$ Log EPG -0.20 Log Hae $(\mathrm{r}=0.71 ; \mathrm{P}<0.001)$.

This nematode species influence was particularly important in:

- lambs: Log Worms $=3.93+0.67$ Log EPG -0.43 Log

Hae $(r=0.76 ; \mathrm{P}<0.001)$, 
- and in goats: Log Worms $=2.55+0.85$ Log EPG 0.47 Log Hae $(r=0.83 ; \mathrm{P}<0.001)$,

- but did not increase prediction value in ewes.

\section{FECUNDITY IN RELATION TO WORM BURDEN} MODIFIES THE RELATIONSHIP BETWEEN WORM BURDENS AND FAECAL EGG COUNTS

The values of egg per gram and per worm (EPG/no of worms recovered at necropsy $=\mathrm{EPGW}$ ) were plotted against Log of worm burdens (LW) as shown in Fig. 2. A similar linear relation was established for the temperate and steppic data sets but the Mauritanian data could not be adjusted to such a relation. The EPGW was much higher in sheep and goats from Mauritania (1.66 to 2.73 , data not shown) than in all the other studied hosts from temperate areas studied (from 0.11 in ewes from France to 0.29 in lambs); this is related to the higher frequency of the prolific $H$. contortus in small ruminants (98\% versus 1 to $5 \%$ ) in Mauritania.

The egg per gram and per worm are not a total reflect of fecundity: for a similar number of worms, the eggs are heavily concentrated in smaller sized hosts (Mauritanian young sheep and goats weighed approximately $12 \mathrm{~kg}$ ) that excrete a lesser quantity of faeces, and more diluted in larger size lambs from temperate climates (approximately $25 \mathrm{~kg}$ ), or adult sheep and goats from these latter areas (over $50 \mathrm{~kg}$ ). When a correction for dilution in smaller hosts is taken into account (a mauritanian young sheep is four times lighter than a ewe from temperate or steppic climate, a lamb is twice lighter than a ewe in temperate or steppic conditions), i.e. the same number of excreted eggs per female worm in faeces will appear twice higher in a lamb than in a ewe, then the range of fer-
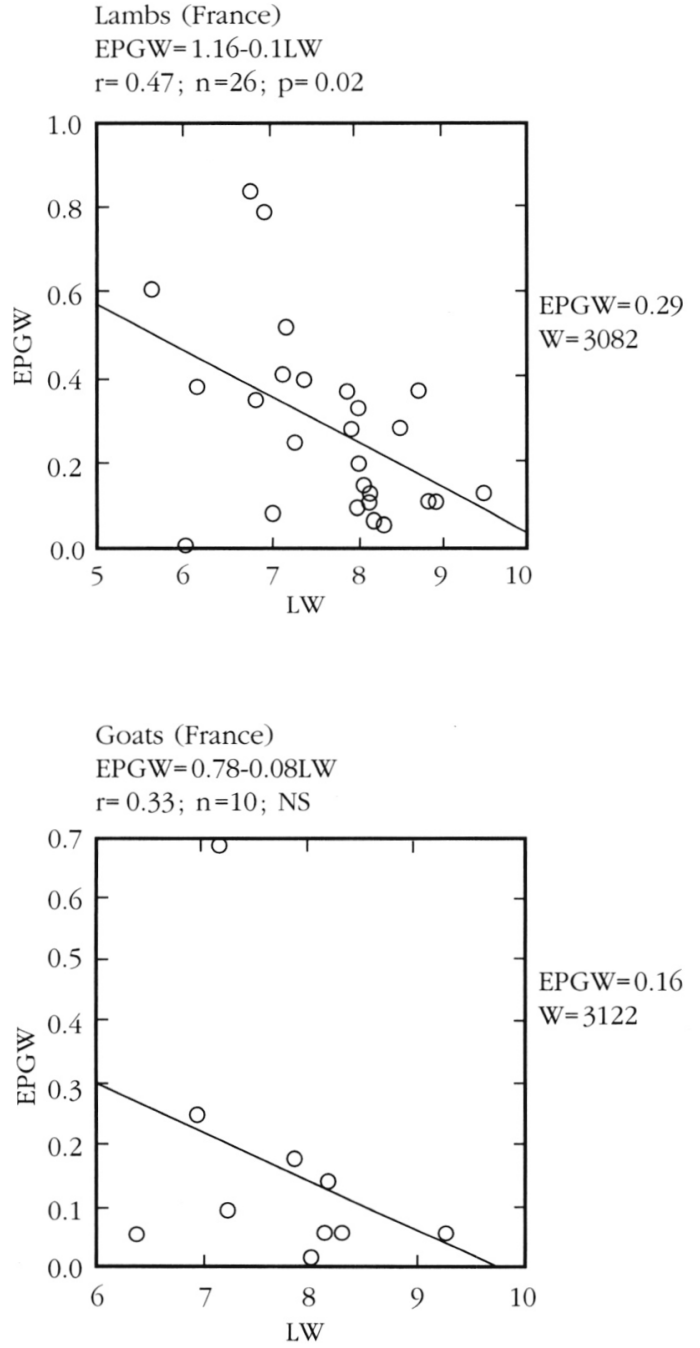

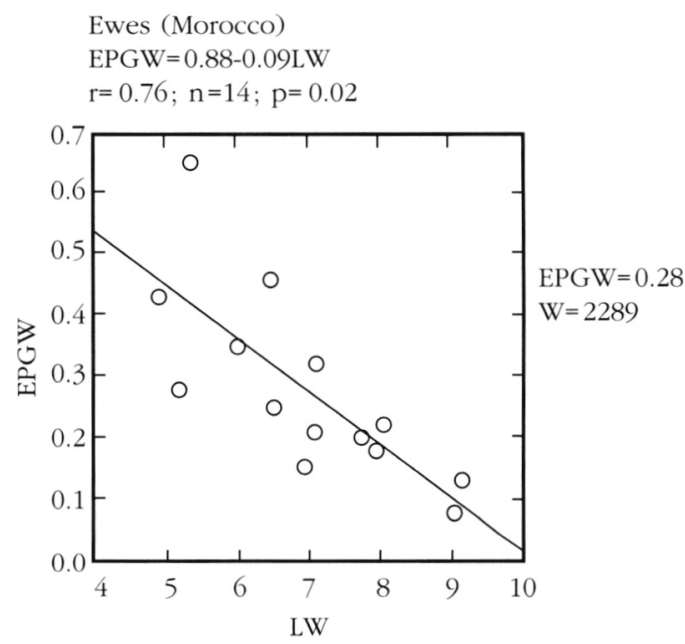

Sheep and goats (Mauritania) NS

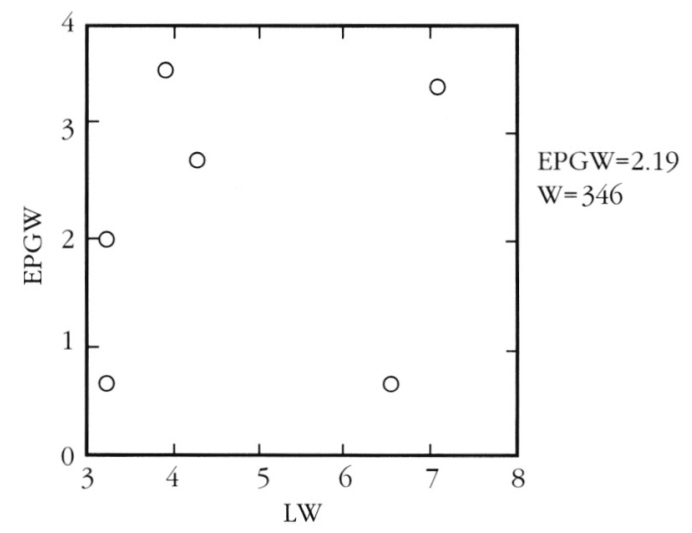

Fig. 2. Strongyle fecundity expressed as egg per gram of faeces and per worm (EPGW) in relation to the natural logarithm of worm burden (LW) using pooled data in four host-environmental conditions. (The values on the right of each graph correspond to average fecundity and worm burden). 
tility is reduced: $0.41-0.68$ for mauritanian sheep and goats, 0.09-0.15 for lambs and 0.11-0.28 EPGW adjusted for host size for ewes and dairy-goats.

\section{DISCUSSION}

$\mathrm{K}$

eymer \& Slater (1987) found that there was: i) a very high variability in per capita nemathreshold worm burden, iii) and finally much lower variability in per capita fecundity between heavily infected hosts. The points i and iii were not evidenced in our data (Fig. 1), possibly due to the existence of much higher worm numbers in the trichostrongyle worms we studied (from several hundred worms to thousands) than in the parasitic infections of man reviewed by Keymer \& Slater, 1987 (from few worms to several hundreds in very few hosts). In their examples, density dependence could be a statistical illusion, created by inadequate sampling (the random sampling of few heavily infected hosts), by technical error (inaccuracies in the worm recoveries when very few worms are present) or by the difficulties of interpreting results from horizontal surveys of host populations which have been exposed to infection for varying periods of time. The two first type of errors should not occur in our sample due to the high level of infection, but the last one may interfere. The high per capita nematode fecundity may result from a recent infection in young hosts where immunological constraints have not yet developed or in a host of any age with an immunological defect. The lamb and ewe data from temperate and steppic area do not support the existence of recent infection (lambs) resulting in higher per capita trichostrongyle fecundity compared with older infection (ewes). The worm density in these areas is then a reality that might account for approximately for 10 to $50 \%$ of variance in fecundity (this part of variance is expressed by $\mathrm{r}^{2}$, which ranged from 0.10 : dairy-goats, 0.22 : lambs from France, to 0.52: ewes from Morocco). The relatively low value of $r^{2}$ in dairygoats might be explained by the pooling of the necropsy data of only two goats per farm, of frequently different level of infection. In the case of Mauritanian sheep and goats that were in poor condition most of the time, immunological deficiencies may obscure density dependent fecundity phenomenon (see Fig. 2).

It is well known that fecundity is related to species, either in experimental or natural infection. Thus, female $H$. contortus excreted twice more eggs than M. marshalli, ten times more than T. circumcincta, and hundred times more than Trichostrongylus sp. (Cabaret \& Ouhelli, 1984). The species proportions play a major role in the fecundity of worm communities. In the temperate and steppic data set, the limited occurence of $H$. contortus, the most prolific species, was the general rule; conversely, in Mauritania, the latter species largely predominated in the community. It is then no surprise that Mauritanian data give very different fecundity results from those recorded in temperate and steppic areas. Consequently, introduction in the regression models of the percentage of $H$. contortus, the most prolific species, was a real improvement.

The relationship between egg per gram and worm intensity depends on characteristics of worm communities (intensity and species richness), which are in relation to host susceptibility to infection. Stear et al., 1995, did show in experimental infection with T. circumcincta that: i) variation in local immunoglobulin (IgA) responses regulates worm fecundity, and ii) variation in local immediate hypersensitivity reactions regulates worm burdens, and consequently egg counts. Those two mechanisms could result, when they act independently, in such situations as high number of worms associated with poor fecundity, or low worm burden associated with high fecundity, that will end in similar egg counts. In different hosts and different environments, the relationship between faecal egg and worm counts was surprisingly high in our data. This could be due to the fact that: i) helminthic fauna was not much different in the temperate and steppic conditions, consisting of species with low fertility, ii) and that average infections were of the same magnitude.

Sampling errors remain important as worm burdens (Boag, Hackett \& Topham, 1992) and faecal egg counts (Hunter \& Quenouille, 1952) are very variable between hosts, due to aggregated distribution of the parasites. The natural logarithm transformation stabilized variance but could not reduce completely the negative impact of limited number of faecal samples (Gasbarre et al., 1996) on accuracy of prediction of worm numbers from faecal egg counts. The relationship between faecal egg counts and worm burdens is not an illusion, even if density-dependent phenomenon may partly obscure the relationship, and the faecal egg counts can be used at a group or a flock/herd level as previously demonstrated in sheep in New-Zealand (McKenna, 1987) or dairy-goats in France (Cabaret, Anjorand \& Leclerc, 1986). Conversely, it is not advisable for an individual host, unless repeated measures of egg counts are performed. The quality of the relationship between egg counts and worm burdens should be tested in a larger array of worm communities as the temperate areas investigated here comprised mostly poorly prolific species. The rules for pooling data should be explicited: how many faecal samples are needed, from which type of small ruminants (sheep or goats, young or adult), at which period of the year? 


\section{ACKNOWLEDGEMENTS}

7 his study was funded in part by research contract with "Région Centre" of France on Goat parasitism, A.T.E.R. teaching and research contract from the University of Orléans for N.G., and by French cooperation in Mauritania (F.A.C. and C.I.R.A.D.-E.M.V.T.) for P.J.

\section{REFERENCES}

ANDERSON R.M. \& GORDON D.M. Processes influencing the distribution of parasite numbers within host populations with special emphasis on parasite induced host mortalities. Parasitology, 1982, 85, 373-398.

Boag B., Hackett C.A. \& Topham P.B. The use of Taylor's power law to describe the aggregated distribution of gastro-intestinal nematodes of sheep. International Journal for Parasitology, 1992, 22, 267-270.

CABAret J. \& Ouhelli H. La fertilité des strongles parasites du tube digestif des ovins dans les conditions naturelles. Revue de Médecine vétérinaire, 1984, 135, 627-633.

CABAret J. \& GaSnier N. Farm history and breeding management influences on the intensity and specific diversity of nematode infection of dairy-goats. Veterinary Parasito$\log y, 1994,53,219-232$.

Cabaret J., Anjorand N. \& Leclerc C. Les élevages caprins en Touraine. I. Mode d'élevage, parasitisme et estimation des pathologies chez les chèvres adultes. Recueil de Médecine Vétérinaire, 1986, 162, 575-585.

FLEMING M.W. Size of inoculum dose regulates in part worm burdens, fecundity, and lengths in ovine Haemonchus contortus infections. Journal of Parasitology, 1988, 74 , 975-978.

Gasbarre L.C., Leighton E.A. \& Bryant D. Reliability of a single egg per gram determination as a measure of individual and herd values for trichostrongyle nematodes of cattle. American Journal of Veterinary Research, 1996, 57, 168-171.

GRUNER L. Breeding for helminth resistance in sheep and goats. In: Breeding for resistance in farm animals. Owen J.B. \& Axford R.F.E. C.A.B. International, 1991, pp. 187200 .

Hunter G.C. \& Quenoulle M.H. A statistical examination of the worm egg count sampling technique for sheep. Journal of Helmintbology, 1952, 26, 157-170.

Keymer A.E. \& Slater A.F.G. Helminth fecundity: density dependence or statistical illusion. Parasitology Today, 1987, 3, 56-58.

MCKENNA P.B. The estimation of gastrointestinal strongyle worm burdens in young sheep flocks: a new approach to the interpretation of faecal egg counts. I. Development. New Zealand Veterinary Journal, 1987, 35, 94-97.

Peladeau N. \& Lacouture Y. Simstat: bootstrap computer simulation and statistical program for IBM personal computers. Behav. Res. Meth. Instr. Comp., 1993, 25, 410-413.
Skrjabin K.J., Shikobalova N.P. \& Schultz R.S. Trichostrongylids of Animal and Man. National Scientific Foundation. Department of Agriculture, Washington, 1954, 483 pp.

Stear M.J., Bishop S.C., Doligalska M., Duncan J.L., Holmes P.H., Irvine J., Mccririe L., Mckellar Q.A., Sinski E. \& MURRAY M. Regulation of egg production, worm burden, worm length and worm fecundity by host responses in sheep infected with Ostertagia circumcincta. Parasite Immunology, 1995, 17, 643-652.

Reçu le 18 mars 1997 Accepté le 20 février 1998 